Zukow Walery, Flyunt Igor-Severyn S., Ruzhylo Sofiya V., Koval'chuk Halyna Y., Nahurna Yaryna V., Popovych Dariya V., Sarancha Serhiy M. Forecasting of multivariant changes in Step test under the influence of natural adaptogens. Pedagogy and Psychology of Sport. 2021;7(1):85-93. elSSN 2450-6605. DOI http://dx.doi.org/10.12775/PPS.2021.07.01.005

https://apcz.umk.pl/czasopisma/index.php/PPS/article/view/PPS.2021.07.01.005

https://zenodo.org/record/4548660

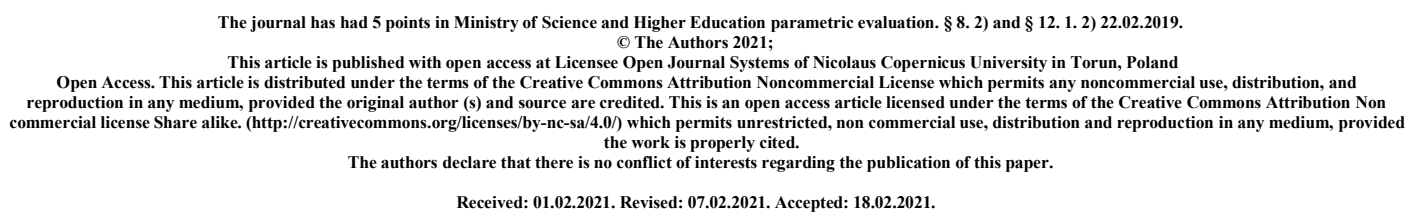

\title{
FORECASTING OF MULTIVARIANT CHANGES IN STEP TEST UNDER THE
} INFLUENCE OF NATURAL ADAPTOGENS

\author{
Walery Zukow ${ }^{1}$, Igor-Severyn S. Flyunt ${ }^{2}$, Sofiya V. Ruzhylo ${ }^{2}$, Halyna Y. Koval'chuk ${ }^{2}$, \\ Yaryna V. Nahurna ${ }^{3}$, Dariya V. Popovych ${ }^{4}$, Serhiy M. Sarancha ${ }^{5}$ \\ ${ }^{1}$ Nicolaus Copernicus University, Torun, Poland w.zukow@wp.pl \\ ${ }^{2}$ Ivan Franko Pedagogical University, Drohobych, Ukraine \\ igorf3007@ukr.net doctor-0701@ukr.net \\ 32Danylo Halyts'ky̌̌ National Medical University, L’viv, Ukraine nyv86@ukr.net \\ ${ }^{4}$ IY Horbachevs'kyi National Medical University, Ternopil', Ukraine \\ ${ }^{5}$ Children's Sanatorium "Dzherelo", Truskavets', Ukraine
}

\begin{abstract}
Summary
Background. Earlier, we found the multivariant nature of the Popovych's step test change in children after a course of adaptogenic balneotherapy. In particular, the step test improved in $53,7 \%$ of children, remained unchanged in $28,8 \%$, and worsened in $17,5 \%$. The purpose of this study is to identify predictors that allow us to forecast each variation of the step test. Material and methods. Object of observation was 80 children of both sexes, ages 10-17, arriving at the clinical sanatorium "Dzherelo" of Truskavets' spa from radionuclide contaminated territories. The main parameter of the study was the Popovych's step test. State of autonomous nervous, endocrine and immune systems was assessed as well as others functional and metabolic tests. Results. Discriminant analysis was subsequently applied to identify constellations of parameters-predictors of each variant of change in step test. The program selected 16 initial parameters as predictors (primarily level of step test, next sex, body mass and temperature, levels of Gench's and Teslenko's tests, vagal tone, erythrocytes sedimentation rate, trombocytes level as well as 7 immune parameters). The correctly of forecasting of the positive actotropic effect is $90,7 \%$; of neutral is $78,3 \%$; of negative is $92,9 \%$, and total correctness is $87,5 \%$. Conclusion. Balneotherapy causes multivariate changes in Popopvych's step test, which determined by constellation of 16 initial parameters.
\end{abstract}

Key words: Step test; HRV; Hormones; Immunity; Metabolism; Balneotherapy; Children; Forecasting. 


\section{INTRODUCTION}

Earlier, we found the multivariant nature of the Popovych's step test change in children after a course of adaptogenic balneotherapy. In particular, the step test improved in $53,7 \%$ of children, remained unchanged in $28,8 \%$, and worsened in $17,5 \%$ [34]. The purpose of this study is to identify predictors that allow us to forecast each variation of the step test.

\section{MATERIAL AND METHODS}

The object of observation was 80 children (48 boys and 32 girls), ages 10-17, arriving at the clinical sanatorium "Dzherelo" of Truskavets' spa from radionuclide contaminated territories (density ${ }^{137} \mathrm{Cs} 37 \div 93 \mathrm{kBq} / \mathrm{m}^{2}$ ). According to $\gamma$-spectrometry performed with a human radiation meter "Screensaver-3M", the activity of incorporated ${ }^{137} \mathrm{Cs}$ was $1,5 \div 35$ $\mathrm{Bq} / \mathrm{kg}$. No somatic pathology was detected in most children, 14 were diagnosed with chronic cholecystitis/cholangitis or gastroduodenitis, and another 14 were diagnosed with combined pathology.

The main subject of the study was the Popovych's step test [30,32,34]. State of autonomous nervous system was assessed by the method of HRV [1] using the "Cardio" device (Kyiv). Also, on the basis of levels of heart rate sitting and standing calculated Teslenko's index [5]. Among hormones determined Cortisol, Aldosterone, Testosterone and Triiodothyronine (by the ELISA with the use of analyzers "Tecan" and "RT-2100C" and corresponding sets of reagents from “Алкор Био" and XEMA Co., Ltd).

The level of hemoglobin, erythrocytes, erythrocytes sedimentation rate, trombocytes and leukocytes was determined. We counted up Leukocytogram (LCG) (Eosinophils, Stub and Segmentonucleary Neutrophils, Lymphocytes and Monocytes) and calculated its Adaptation Index as well as Entropy by Popovych IL [11,22,25,].

Lymphocyte phenotypes (markers CD3, CD4, CD8, CD16, CD19) were determined by the method of indirect immunofluorescence reaction of binding of monoclonal antibodies of "Sorbent" with visualization under a fluorescence microscope. Theophylline-resistant and theophylline-sensitive T-lymphocyte subpopulations, serum levels of $\mathrm{G}, \mathrm{A}, \mathrm{M}$ immunoglobulins (radial immunodiffusion method) and circulating immune complexes (polyethylene glycol precipitation method) were also determined. The state of the phagocytic link of immunity was judged by the activity of phagocytosis (phagocytic index), its intensity (microbial count) and completeness (killing index) against Staphylococcus aureus, with the calculation of bactericidal ability of neutrophils. Serum lysozyme activity was evaluated in the bacteriolysis test of Micrococcus lysodeikticus. To assess local immunity, lysozyme activity in mixed saliva was determined. Used the methodologies in the manuals $[9,19,21]$.

Anfimov's corrective test was conducted to assess mental performance, as well as the classic Stange's and Gench's breath delaying tests for inspiration and expiration, respectively $[25,30,32]$.

In the vein of functional-metabolic continuum concept [6] an oral glucose tolerance test (OGTT) was also performed.

Results processed by methods of discriminant analyses, using the software package "Statistica 5.5".

\section{RESULTS}

In order to identify predictors of the three variants of the step test change, all registered initial parameters of children were subjected to discriminant analysis by the forward stepwise method [10]. 
The program included only 16 initial parameters in the discriminant model (tables 1 and 2). These were, in addition to the expected step test index, Teslenko's and Gench's tests, HRV-marker of vagal tone, sex-index as the ratio between boys (0) and girls (1), body weight, normalized by sex and age, platelet count, erythrocytes sedimentation rate as well as seven immune parameters (leukocytes level, relative content of eosinophils, total lymphocytes, populations of natural killers and theophylline-resistant $\mathrm{T}$ lymphocytes, intensity of phagocytosis of Staphylococcus aureus by neutrophils and serum IgA level) as well as not expected evening, but not morning body temperature.

Other registered initial parameters of the organism were outside the model. However, 19 of them deserve attention in terms of predicting the nature of the impact of balneotherapy on the step test.

Table 1. Discriminant Function Analysis Summary for Predictors of Changes in Popovych's Step Test

Step 16, N of vars in model: 16; Grouping: 3 grps

Wilks' Lambda: 0,2419 ; approx. $\mathrm{F}_{(32,1)}=4,0 ; \mathrm{p}<10^{-6}$

\begin{tabular}{|c|c|c|c|c|c|c|c|c|c|}
\hline \multirow[b]{2}{*}{$\begin{array}{l}\text { Variables-predictors currently } \\
\text { in the model }\end{array}$} & \multicolumn{3}{|c|}{ Changes in Popovych's Step Test } & \multicolumn{5}{|c|}{ Parameters of Wilks' Statistics } & \multirow[b]{2}{*}{$\begin{array}{l}\text { Reference } \\
\text { level } \\
(\mathbf{3 0}) \\
\end{array}$} \\
\hline & $\begin{array}{l}\text { PST- } \\
(14)\end{array}$ & $\begin{array}{l}\text { PST }_{0} \\
(23)\end{array}$ & $\begin{array}{l}\text { PST+ } \\
(43)\end{array}$ & $\begin{array}{l}\text { Wilk } \\
\mathrm{s} \\
\Lambda \\
\end{array}$ & $\begin{array}{l}\text { Par- } \\
\text { tial } \\
\Lambda \\
\end{array}$ & $\begin{array}{l}\text { F- } \\
\text { remo } \\
\text { ve } \\
\end{array}$ & $\begin{array}{l}\text { p- } \\
\text { le- } \\
\text { vel } \\
\end{array}$ & $\begin{array}{l}\text { To- } \\
\text { lera } \\
\text { ncy } \\
\end{array}$ & \\
\hline Popovych Step Test, p-ts & $0,71 \pm 0,04$ & $0,63 \pm 0,03$ & $0,55 \pm 0,01$ & ,289 & ,838 & 6,0 & ,004 & ,530 & $0,68 \pm 0,03$ \\
\hline CD16 $^{+}$NK Lymphoc, $\%$ & $19,7 \pm 2,2$ & $14,2 \pm 0,9$ & $14,4 \pm 0,7$ & ,287 &, 843 & 5,8 &, 005 &, 190 & $15,6 \pm 1,5$ \\
\hline Teslenko's Test, points & $4,8 \pm 0,5$ & $4,3 \pm 0,4$ & $3,2 \pm 0,3$ & ,256 & ,945 & 1,8 &, 174 & ,758 & $7,0 \pm 0,2$ \\
\hline Trombocytes, G/L & $280 \pm 9$ & $255 \pm 8$ & $250 \pm 6$ & ,265 & ,913 & 3,0 &, 060 & ,704 & $275 \pm 3$ \\
\hline Sex Index, points & $0,57 \pm 0,14$ & $0,43 \pm 0,11$ & $0,33 \pm 0,07$ & ,345 & ,702 & 13,2 & $10^{-4}$ & ,411 & $0 \div 1$ \\
\hline Body Mass, \% of norm & $108,9 \pm 4,6$ & $100,2 \pm 2,2$ & $102,2 \pm 2,1$ & ,291 & ,830 & 6,3 & ,003 & ,638 & $100 \pm 1,8$ \\
\hline MxDMn as Vagotone, sec & $0,34 \pm 0,03$ & $0,28 \pm 0,03$ & $0,29 \pm 0,02$ & ,259 & ,935 & 2,1 & ,126 & ,712 & $0,22 \pm 0,02$ \\
\hline Microbial Count, Bac/Ph & $3,8 \pm 0,2$ & $4,0 \pm 0,2$ & $4,7 \pm 0,2$ &, 255 & ,949 & 1,7 &, 196 & ,704 & $7,0 \pm 0,3$ \\
\hline Pan Lymphocytes, \% & $26,6 \pm 2,2$ & $34,9 \pm 1,7$ & $33,2 \pm 1,2$ & ,253 & ,957 & 1,4 & ,259 &, 213 & $35,5 \pm 1,1$ \\
\hline Theophyl Res T Lym., \% & $31,5 \pm 1,0$ & $36,5 \pm 2,1$ & $34,8 \pm 1,2$ & ,274 & ,882 & 4,2 & ,020 & ,318 & $42,0 \pm 1,8$ \\
\hline Leukocytes total, G/L & $5,78 \pm 0,35$ & $6,12 \pm 0,26$ & $5,31 \pm 0,12$ & ,256 & ,943 & 1,9 & ,163 &, 865 & $5,00 \pm 0,18$ \\
\hline Eryth Sedim Rate, $\mathrm{mm} / \mathrm{h}$ & $6,1 \pm 0,7$ & $7,4 \pm 0,7$ & $6,2 \pm 0,4$ & ,262 & ,922 & 2,6 & ,082 & ,585 & $8,0 \pm 0,5$ \\
\hline Gench's Test, sec & $30,9 \pm 2,7$ & $32,8 \pm 3,3$ & $26,5 \pm 1,6$ & ,265 & ,912 & 3,0 & ,057 & ,790 & $26 \pm 1$ \\
\hline IgA Serum, g/L & $1,45 \pm 0,22$ & $1,57 \pm 0,19$ & $1,21 \pm 0,08$ & ,254 & ,951 & 1,6 & ,210 & ,813 & $1,90 \pm 0,18$ \\
\hline Body Temperat Even, ${ }^{0} \mathrm{C}$ & $36,48 \pm 0,06$ & $36,41 \pm 0,05$ & $36,52 \pm 0,03$ & ,274 &, 884 & 4,1 &, 022 & ,607 & $36,60 \pm 0,02$ \\
\hline Eosinophiles, \% & $3,3 \pm 0,5$ & $3,0 \pm 0,5$ & $3,2 \pm 0,4$ &, 258 & ,936 & 2,1 &, 128 &, 714 & $2,75 \pm 0,16$ \\
\hline $\begin{array}{l}\text { Variables-predictors currently } \\
\text { not in the model }\end{array}$ & $\begin{array}{l}\text { PST- } \\
\text { (14) }\end{array}$ & $\begin{array}{l}\text { PST }_{0} \\
(23)\end{array}$ & $\begin{array}{l}\text { PST+ } \\
(43)\end{array}$ & $\begin{array}{l}\text { Wilk } \\
\mathrm{s} \\
\Lambda \\
\end{array}$ & $\begin{array}{l}\text { Par- } \\
\text { tial } \\
\Lambda \\
\end{array}$ & $\begin{array}{l}\text { F to } \\
\text { en- } \\
\text { ter } \\
\end{array}$ & $\begin{array}{l}\text { p- } \\
\text { le- } \\
\text { vel } \\
\end{array}$ & $\begin{array}{l}\text { To- } \\
\text { lera } \\
\text { ncy } \\
\end{array}$ & $\begin{array}{l}\text { Reference } \\
\text { level } \\
(\mathbf{3 0}) \\
\end{array}$ \\
\hline Cortisol, $\mathrm{nM} / \mathrm{L}$ & $726 \pm 58$ & $556 \pm 36$ & $604 \pm 27$ & ,238 & ,983 &, 52 & ,599 & , 586 & $396 \pm 19$ \\
\hline Theoph Sens T Lym., \% & $22,6 \pm 0,9$ & $18,5 \pm 1,2$ & $18,6 \pm 1,0$ & ,229 & ,948 & 1,67 & ,196 & ,196 & $19,3 \pm 1,1$ \\
\hline CD8 $^{+}$T Lymphocytes, $\%$ & $25,9 \pm 0,7$ & $23,4 \pm 0,9$ & $23,2 \pm 0,8$ & ,229 & ,947 & 1,71 & ,190 & ,218 & $24,7 \pm 0,8$ \\
\hline CIC, units & $35 \pm 7$ & $50 \pm 6$ & $55 \pm 5$ & ,239 & ,987 &, 41 & ,664 & ,353 & $44 \pm 4$ \\
\hline Phagocytose Index, \% & $50,3 \pm 1,8$ & $55,5 \pm 1,4$ & $56,7 \pm 1,5$ & ,240 & ,994 &, 18 & ,835 & ,756 & $73,5 \pm 2,1$ \\
\hline Killing Index, \% & $46,9 \pm 2,1$ & $53,4 \pm 2,1$ & $53,0 \pm 2,1$ &, 240 & ,994 &, 18 &, 835 &, 715 & $68,6 \pm 2,9$ \\
\hline Baevski Stress Index, In & $4,06 \pm 0,24$ & $4,41 \pm 0,20$ & $4,46 \pm 0,13$ & ,239 & ,989 & ,34 & ,711 &, 101 & $4,84 \pm 0,08$ \\
\hline AMo as Symp. Tone, \% & $32,7 \pm 3,6$ & $36,3 \pm 2,9$ & $38,6 \pm 1,8$ & ,240 & ,993 & 23 & ,797 & ,331 & $39,8 \pm 1,6$ \\
\hline CD4 $^{+}$T Lymphocytes, \% & $28,0 \pm 0,5$ & $31,1 \pm 1,1$ & $30,3 \pm 0,7$ & ,229 & ,947 & 1,71 & ,189 &, 013 & $33,6 \pm 0,9$ \\
\hline Pan Lymphocytes, $10^{9} / \mathrm{L}$ & $1,56 \pm 0,17$ & $1,96 \pm 0,14$ & $1,69 \pm 0,09$ & ,240 & ,991 &, 28 & ,758 &, 235 & $2,12 \pm 0,25$ \\
\hline Entropy of LCG, $\bullet 10^{3}$ & $606 \pm 19$ & $646 \pm 12$ & $631 \pm 8$ & ,241 & ,997 &, 08 & ,926 & ,336 & $685 \pm 11$ \\
\hline Morbidity Index & $0,50 \pm 0,23$ & $0,74 \pm 0,18$ & $0,42 \pm 0,11$ & ,236 & ,977 &, 71 & ,494 & ,564 & 0 \\
\hline Rod Neutrophils, $\%$ & $2,9 \pm 0,4$ & $3,9 \pm 0,4$ & $3,45 \pm 0,2$ & ,241 & ,998 &, 05 & ,954 & ,584 & $3,25 \pm 0,11$ \\
\hline Monocytes, \% & $3,0 \pm 0,4$ & $4,0 \pm 0,4$ & $3,45 \pm 0,2$ & ,241 & ,998 & ,08 & ,928 &, 576 & $6,0 \pm 0,2$ \\
\hline Hemoglobin, \% of norm & $93,1 \pm 1,3$ & $95,1 \pm 0,9$ & $92,4 \pm 0,7$ & ,239 & ,987 & ,41 & ,667 &, 535 & $100 \pm 1,8$ \\
\hline Popovych's Adaptat Ind & $0,72 \pm 0,10$ & $0,69 \pm 0,08$ & $0,83 \pm 0,06$ & ,239 & ,990 & ,31 & ,736 & ,788 & $1,70 \pm 0,04$ \\
\hline Segmented Neutroph, \% & $58,4 \pm 2,0$ & $51,0 \pm 1,8$ & $54,4 \pm 1,2$ & ,237 & ,978 & ,69 & ,506 &, 520 & $52,5 \pm 1,6$ \\
\hline Body Mass, kg & $53,5 \pm 3,8$ & $46,1 \pm 2,5$ & $48,2 \pm 1,8$ & ,222 & ,980 & ,61 & ,548 & ,204 & \\
\hline Age, years & $13,6 \pm 0,7$ & $12,9 \pm 0,9$ & $13,3 \pm 0,3$ & ,240 & ,994 &, 18 &, 835 &, 715 & \\
\hline
\end{tabular}


Table 2. Summary of Stepwise Analysis for Predictors of Changes in Popovych's Step Test. The variables are ranked by criterion Lambda

\begin{tabular}{|l|l|l|l|l|l|}
\hline & $\begin{array}{l}\text { F to } \\
\text { enter }\end{array}$ & $\begin{array}{l}\text { p- } \\
\text { level }\end{array}$ & $\Lambda$ & $\begin{array}{l}\text { F- } \\
\text { value }\end{array}$ & $\begin{array}{l}\text { p- } \\
\text { level }\end{array}$ \\
\hline Popovych Step Test, points & 8,9 &, 0003 &, 812 & 8,9 &, 000325 \\
\hline Sex Index, points & 11,0 &, 0001 &, 629 & 9,9 &, 000000 \\
\hline CD16+ NK Lymphocytes, \% & 5,8 &, 0046 &, 545 & 8,9 &, 000000 \\
\hline Theophylline Resistent T Lymph., \% $^{+}$ & 4,3 &, 0169 &, 488 & 8,0 &, 000000 \\
\hline Leukocytes total, G/L & 3,7 &, 0302 &, 444 & 7,3 &, 000000 \\
\hline Body Mass, \% of norm & 2,3 &, 1033 &, 417 & 6,6 &, 000000 \\
\hline Body Temperature Evening, ${ }^{\mathbf{C}} \mathbf{C}$ & 2,3 &, 1092 &, 391 & 6,1 &, 000000 \\
\hline Hench's Test, sec & 3,5 &, 0365 &, 356 & 5,9 &, 000000 \\
\hline IgA Serum, g/L & 2,1 &, 1253 &, 335 & 5,6 &, 000000 \\
\hline Trombocytes, G/L & 1,5 &, 2289 &, 321 & 5,2 &, 000000 \\
\hline Erythrocytes Sedimentation Rate, $\mathbf{m m / h} \mathbf{h}$ & 1,6 &, 2145 &, 307 & 4,9 &, 000000 \\
\hline Teslenko's Test, points & 1,8 &, 1810 &, 291 & 4,7 &, 000000 \\
\hline MxDMn HRVas Vagal tone, sec & 1,5 &, 2205 &, 278 & 4,5 &, 000000 \\
\hline Eosinophiles, \% & 1,7 &, 1821 &, 264 & 4,3 &, 000000 \\
\hline Microbial Count, Bac/Phag & 1,4 &, 2635 &, 253 & 4,2 &, 000000 \\
\hline Pan Lymphocytes, \% & 1,4 &, 2593 &, 242 & 4,0 &, 000000 \\
\hline
\end{tabular}

Next, the 16-dimensional space of discriminant variables transforms into 2-dimensional space of canonical roots. The canonical correlation coefficient is for Root 10,790 (Wilks' $\Lambda=0,242 ; \chi^{2}{ }_{(32)}=99 ; p<10^{-6}$ ) and for Root 20,598 (Wilks' $\Lambda=0,642 ; \chi^{2}{ }_{(15)}=31 ; p=0,010$ ). The major root contains $75 \%$ of discriminative opportunities and the minor is $25 \%$.

Table 3 presents coefficients for discriminant variables. The calculation of the discriminant root values for each child as the sum of the products of raw coefficients to the individual values of discriminant variables together with the constant enables the visualization of each child in the information space of the roots (Fig. 1).

Table 3. Standardized, Structural and Raw Coefficients and Constants for Predictors

\begin{tabular}{|c|c|c|c|c|c|c|}
\hline \multirow[t]{2}{*}{ Coefficients } & \multicolumn{2}{|c|}{ Standardized } & \multicolumn{2}{|c|}{ Structural } & \multicolumn{2}{|c|}{ Raw } \\
\hline & $\begin{array}{l}\text { Root } \\
1\end{array}$ & $\begin{array}{l}\text { Root } \\
2\end{array}$ & $\begin{array}{l}\text { Root } \\
1\end{array}$ & $\begin{array}{l}\text { Root } \\
2\end{array}$ & $\begin{array}{l}\text { Root } \\
1\end{array}$ & $\begin{array}{l}\text { Root } \\
2\end{array}$ \\
\hline Popovych's Step Test, points & ,690 &, 166 & ,368 &, 115 & 5,479 & 1,319 \\
\hline CD16 $^{+}$NK Lymphocytes, \% & ,995 &,- 763 & ,265 &,- 219 &, 182 &,- 140 \\
\hline Teslenko's Test, points &, 332 & ,098 & ,263 &, 192 & 177 & ,052 \\
\hline Trombocytes, G/L & ,383 &,- 299 &, 222 &,- 073 & 010 &,- 008 \\
\hline Sex Index, points & 1,069 &,- 183 & ,147 &, 036 & 2,179 &,- 374 \\
\hline Body Mass, $\%$ of norm & ,626 &,- 243 & ,132 &,- 191 & 046 &,- 018 \\
\hline MxDMn HRVas Vagotone, sec &, 057 &,- 498 & ,096 &,- 146 & 456 & $-4,018$ \\
\hline Microbial Count, Bac/Phagocyt &,- 015 &,- 451 &,- 225 &,- 222 &,- 013 &,- 401 \\
\hline Pan Lymphocytes, \% & ,427 &,- 491 &,- 221 & ,298 &, 053 &,- 061 \\
\hline Theophyl Resist. T Lymph., \% &,- 523 &, 750 &,- 104 & 210 &,- 063 & ,091 \\
\hline Leukocytes total, G/L &, 283 & ,209 &, 153 & ,378 & 276 & ,204 \\
\hline Erythroc Sediment Rate, $\mathrm{mm} / \mathrm{h}$ &,- 364 &, 374 &, 005 & ,255 &,- 134 &, 138 \\
\hline Gench's Test, sec & ,301 & ,392 & ,119 & 246 &, 025 &, 032 \\
\hline IgA Serum, g/L &, 024 &, 410 &, 114 & 245 &, 034 &, 585 \\
\hline Body Temperature Evening, ${ }^{0} \mathrm{C}$ &,- 318 &,- 599 &,- 057 &,- 269 & $-1,729$ & $-3,263$ \\
\hline Eosinophiles, \% &, 219 &,- 410 &, 013 &,- 042 &, 096 &,- 181 \\
\hline Eigenvalues & 1,656 & ,557 & \multicolumn{2}{|c|}{ Constants } & 46,85 & 122,7 \\
\hline & \multicolumn{4}{|c|}{ Discriminant Proportio } & $75 \%$ & $25 \%$ \\
\hline
\end{tabular}


The localization in the extreme right zone of the major root (centroid: $+2,53$ ) of the cluster of children in whom the step test index decreased under the influence of balneotherapy, reflects, first, their maximally increased levels of natural killers, body weight normalized by sex and age, and vagal tone; secondly, maximally for sampling normal levels of step test and platelets and minimally reduced level of Teslenko's index; thirdly, maximally for sampling ratio of girls/boys; fourthly, maximally reduced levels of phagocytosis intensity, relative content of lymphocytes in general and theophylline-resistant subpopulation in particular.

Also noteworthy are parameters that were not formally included in the model: maximally elevated levels of cortisol as well as subpopulations of theophylline-sensitive and $\mathrm{CD}^{+} \mathrm{T}$-lymphocytes - on the one hand, and maximally reduced levels of Baevsky's stress index, sympathetic tone, $\mathrm{CIC}, \mathrm{CD} 4^{+} \mathrm{T}$-lymphocytes as well as activity and completeness of phagocytosis - on the other hand.

The members of the other two clusters list the parameters are smaller/larger (according to the sign of the structural coefficient), and their points are mixed, which reflects the absence of significant differences between them (centroids: $+0,20$ and $-0,93$ respectively).

Instead, these clusters are delimited along the axis of the minor root: centroids $+1,15$ and $-0,41$ for the "neutral" and "positive" clusters, respectively. The lower position of children in whom the step test index increased reflects their reduced erythrocyte sedimentation rate and IgA level as well as normal levels of leukocytes and Gench's test, while in children with a stable step test index, these parameters are normal or elevated, respectively. On the other hand, in children of a "positive" cluster, the evening body temperature is quite normal, and the level of eosinophils is upper limit, while in a "neutral" cluster, the temperature and eosinophilia are slightly lower.

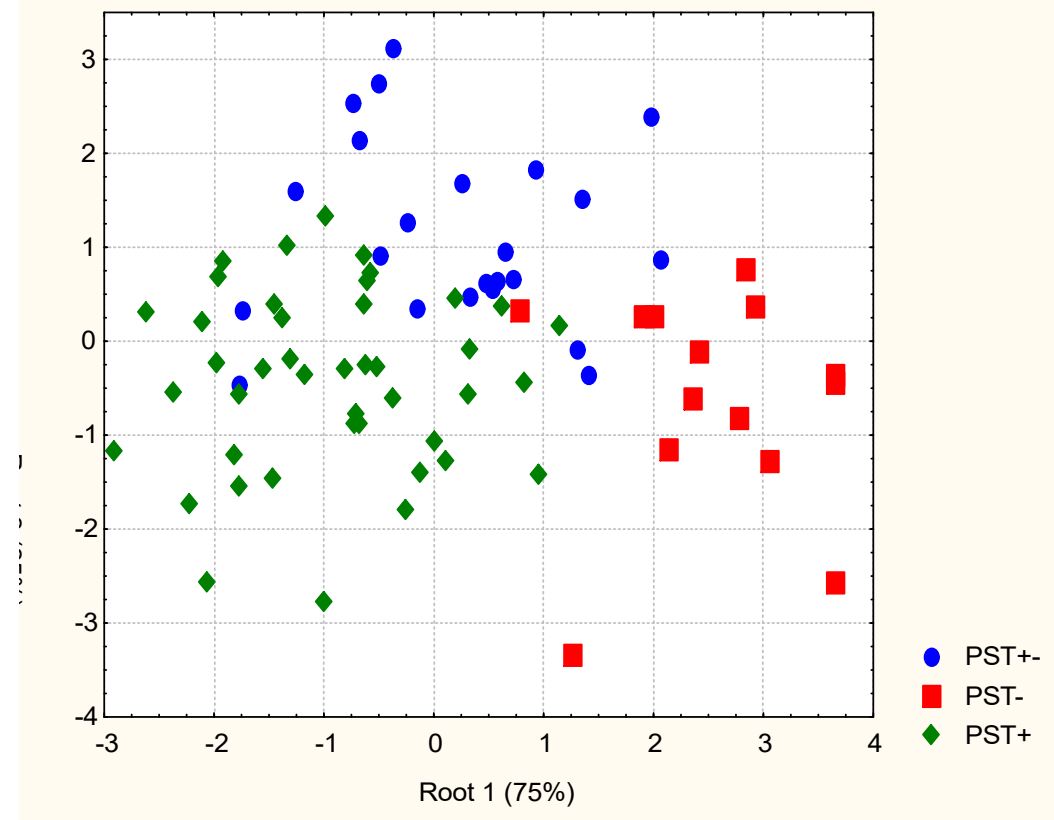

Fig. 1. Scatterplot of individual values of the first and second roots in which condensed information about of the predictors of changes in Popovych's step test of the members of the three clusters

Among the extramodel parameters, the "positive" cluster members have a reduced hemoglobin level, reduced lymphocyte and monocyte proportions in the leukocytogram and reduced entropy of the latter, while the normal proportion of rod neutrophils, while the "neutral" cluster members have a highest level of these parameters. On the other hand, members of the "positive" cluster have a higher level of segment nuclear neutrophils, 
Popovych's leukocytary adaptation index, body weight and age, while a lower morbidity index, calculated as the average number of diagnoses in a child $(0 ; 1 ; 2)$.

In a set of 16 predictors, the three clusters of changes in the index of the step test differ significantly from each other, as documented by the calculation of Mahalanobis distances (Table 4).

Table 4. Squared Mahalanobis Distances (above diagonal), F-values $(\mathrm{df}=17)$ and $p$-levels (below diagonal)

\begin{tabular}{|l|l|l|l|}
\hline Clusters & PST $_{\mathbf{0}}$ & PST- & PST+ \\
\hline PST $_{\mathbf{0}}$ & 0,00 & 8,86 & 3,85 \\
\hline PST- & 3,64 & 0,00 & 12,46 \\
& $<10^{-3}$ & & \\
\hline PST+ & $\begin{array}{l}2,80 \\
0,002\end{array}$ & $\begin{array}{l}6,23 \\
<10^{-6}\end{array}$ & 0,00 \\
\hline
\end{tabular}

The ultimate goal of discriminant analysis - predicting the nature of changes in the index of the step test - is realized using classifying functions (Table 5). These functions are special linear combinations that maximize differences between groups and minimize dispersion within groups. The coefficients of the classifying functions are not standardized, therefore they are not interpreted. An object belongs to a group with the maximum value of a function calculated by summing the products of the values of the variables by the coefficients of the classifying functions plus the constant.

Table 5. Coefficients and Constants for Classification Functions of Clusters

\begin{tabular}{|l|l|l|l|}
\hline \multicolumn{1}{|c|}{ Clusters } & PST+ & PST $_{\mathbf{0}}$ & PST- \\
\hline Predictors & $\mathrm{p}=, 538$ & $\mathrm{p}=, 287$ & $\mathrm{p}=, 175$ \\
\hline Popovych Step Test, points & $-273,7$ & $-265,4$ & $-255,0$ \\
\hline Sex Index, points & $-115,4$ & $-113,5$ & $-107,8$ \\
\hline CD16 ${ }^{+}$NK Lymphocytes, \% & 15,93 & 15,92 & 16,59 \\
\hline Theophyl Resistant T Lymph., \% & $-16,13$ & $-16,06$ & $-16,37$ \\
\hline Leukocytes total, G/L & 47,71 & 48,33 & 48,62 \\
\hline Body Mass, \% of norm & $-2,64$ & $-2,62$ & $-2,48$ \\
\hline Body Temperature Evening, ${ }^{\mathbf{0}} \mathbf{C}$ & 1774 & 1767 & 1768 \\
\hline Gench's Test, sec & $-7,76$ & $-7,69$ & $-7,69$ \\
\hline IgA Serum, g/L & $-78,11$ & $-77,16$ & $-78,11$ \\
\hline Trombocytes, G/L &, 98 &, 98 & 1,01 \\
\hline Erythroc Sedimentat Rate, mm/h & 7,08 & 7,14 & 6,59 \\
\hline Teslenko's Test, points & $-9,54$ & $-9,26$ & $-8,94$ \\
\hline MxDMn HRVas Vagal tone, sec & 350,2 & 344,4 & 352,6 \\
\hline Eosinophiles, \% & 1,24 & 1,06 & 1,61 \\
\hline Microbial Count, Bact/Phagocyte & 25,07 & 24,43 & 25,10 \\
\hline Pan Lymphocytes, \% & 17,99 & 17,96 & 18,19 \\
\hline \multicolumn{1}{|c|}{ Constants } & -32500 & -32257 & -32367 \\
\hline
\end{tabular}

As you can see (Table 6), the accuracy of the prediction of the decrease of the step test index is $92,9 \%$ (one error per 14 children), the increase of the index is assumed with an accuracy of $90,7 \%$ ( 4 errors per 43 children), and no changes - with accuracy 78,3\% (5 errors per 23 children). 
Table 6. Classification Matrix for Clusters

Rows: Observed classifications; Columns: Predicted classifications

\begin{tabular}{|l|l|l|l|l|}
\hline & Percent & PST + & PST $_{\mathbf{0}}$ & PST- \\
\cline { 3 - 5 } Clusters & correct & $\mathrm{p}=, 538$ & $\mathrm{p}=, 287$ & $\mathrm{p}=, 175$ \\
\hline PST+ & 90,7 & $\mathbf{3 9}$ & $\mathbf{4}$ & 0 \\
\hline PST $_{\mathbf{0}}$ & 78,3 & $\mathbf{3}$ & $\mathbf{1 8}$ & $\mathbf{2}$ \\
\hline PST- & 92,9 & 0 & $\mathbf{1}$ & $\mathbf{1 3}$ \\
\hline Total & 87,5 & 42 & 23 & 15 \\
\hline
\end{tabular}

\section{DISCUSSION}

First of all, it should be noted that the polyvariance of the changes of the step test index under the influence of balneofactors of the Truskavets' spa [34] is a separate manifestation of the polyvariance of balneoeffects on the functional state of the organism. Previously described various changes in the parameters of urination, cholekinetics, gastric and pancreatic secretion, hemodynamics, metabolism, hemostasis, immunity, autonomic and endocrine regulation in rats and humans [2-4,11-18,20,25-27,29-33]. As a rule, changes occur according to the law of the initial level and have a normalizing direction [2], characteristic of the action of adaptogens [11,25]. However, in some cases there is a further decline in reduced parameters or an increase in elevated [11,18,31], similar to individual immune responses to chronic stress [7]. We assume that this is due to the individual reactivity of the organism, which is determined by the state of the nervous, endocrine and immune systems, which interact closely $[7,11,18,25]$. It is shown that the main balneofactors of the Truskavets' spa (Naftussya water and Ozokerite) with their organic substances and autochthonous microflora $[8,23-25,28]$ have a modulating effect on these main regulatory systems.

Unexpected prognostic ability of body temperature can be explained by its connection with the level of interleukin-1.

Another aspect of the discussion is the comparison of our results on the possibility of predicting the nature of the actotropic effects of balneofactors of Truskavets' spa with those obtained previously with the participation of one of the authors. In the observation of 42 adult patients of both sexes, in whom physical performance was assessed by the index of tachycardic-hypertensive response to veloergometric load, the accuracy of the prognosis of a positive actotropic effect was $81,0 \%$; uncertain $-60,0 \%$; negative $-72,7 \%$, total correctness $75,6 \%$. Of the 72 initial signs taken into account, 10 were predictors: tachycardichypertensive reaction index, Klimov's atherogenic coefficient, cholesterol content in the composition of very low-density lipoproteins, sodium content in erythrocytes, activity of $\mathrm{Na}$, K-ATPase of erythrocyte shadows, level of diastolic and systolic blood pressure, content of potassium and uric acid in plasma, as well as Ruzhylo-Popovych's index of contractile activity of myocardium [30].

In 18 rats, in order to predict the nature of the actotropic effect of 3-week Naftussya water intake, 6 initial signs were taken into account: dynamic physical performance - by the duration of swimming to exhaustion, static physical performance - by retention on a vertical pole, urine concentration of $\mathrm{Na}^{+}$and $\mathrm{K}^{+}$, daily diuresis and body weight. The first 4 signs were prognostic. Even such scant information was sufficient to predict a significant increase in swimming duration in $33,3 \%$ of animals with an accuracy of $83,3 \%$, a moderate increase in $44,4 \%$ - with an accuracy of $100 \%$, and a reduction in swimming duration in $22,2 \%$ of rats with an accuracy of $88,9 \%$. The overall accuracy of the forecast was $88,9 \%$ [32].

Taken together, these and previous results indicate that the polyvariance of actotropic effects of balneofactors of Truskavets; spa is due to the individual reactivity of the organism and can be reliably predicted. 


\section{ACKNOWLEDGMENT}

We express sincere gratitude to colleagues of clinical sanatorium "Dzherelo" for help in conducting this investigation.

\section{ACCORDANCE TO ETHICS STANDARDS}

Tests in patients are conducted in accordance with positions of Helsinki Declaration 1975, revised and complemented in 2002, and directive of National Committee on ethics of scientific researches. During realization of tests from all parent of participants the informed consent is got and used all measures for providing of anonymity of participants.

For all authors any conflict of interests is absent.

\section{REFERENCES}

1. Baevskiy RM, Ivanov GG. Heart Rate Variability: theoretical aspects and possibilities of clinical application [in Russian]. Ultrazvukovaya i funktsionalnaya diagnostika. 2001; 3: 106127.

2. Balanovs'kyi VP, Popovych IL, Karpynets' SV. About ambivalence-equilibratory character of influence of curative water Naftussya on organism of human [in Ukrainian]. Dopovidi ANU. Mat., pryr., tekhn. Nauky. 1993; 3: 154-158.

3. Chebanenko OI, Chebanenko LO, Popovych IL. Variety Balneoeffects of Factors Spa Truskavets' and their Forecast [in Ukrainian]. Kyiv. UNESCO-SOCIO; 2012: 496 p.

4. Chebanenko OI, Flyunt IS, Tserkovnyuk RG, Popovych IL, Alyeksyeyev OI, Kyjenko VM. Rehabilitation of Defensive and Adaptive Systems on Truskavets' Spa [in Ukrainian]. Kyiv. UNESCO-SOCIO; 2004: 448 p.

5. Druz' VA. Sports Training and Body [in Russian]. Kyiv. Zdorovya; 1980: 128 p.

6. Gozhenko AI. Functional-metabolic continuum [in Russian]. J NAMS of Ukraine. 2016; 22(1): 3-8.

7. Gozhenko AI, Zukow W, Polovynko IS, Zajats LM, Yanchij RI, Portnichenko VI, Popovych IL. Individual Immune Responses to Chronic Stress and their Neuro-Endocrine Accompaniment. RSW. UMK. Radom. Torun; 2019: 200 p.

8. Ivassivka SV, Bubnyak AB, Kovbasnyuk MM, Popovych IL. Genesis and role of phenols in waters from Naftussya layer [in Ukrainian]. In: Problems of pathology in experiment and clinic. Scientific works of Drohobych Medical Institute. Vol. XV. Drohobych; 1994: 6-11.

9. Khaitov RM, Pinegin BV, Istamov KhI. Ecological Immunology [in Russian]. Moskva. VNIRO; 1995: $219 \mathrm{p}$.

10. Klecka WR. Discriminant Analysis [trans. from English in Russian] (Seventh Printing, 1986). In: Factor, Discriminant and Cluster Analysis. Moskva. Finansy i Statistika; 1989: 78-138.

11. Kostyuk PG, Popovych IL, Ivassivka SV (editors). Chornobyl', Adaptive and Defensive Systems, Rehabilitation [in Ukrainian]. Kyiv. Computerpress; 2006: 348 p.

12. Kozyavkina NV. Neuro-endocrine and electrolyte accompaniment of polyvariant thyrotropic effects of bioactive water Naftussya. Medical Hydrology and Rehabilitation. 2009; 7(1): 51-55.

13. Kozyavkina NV. Thyrotropic effects of bioactive water Naftussya in female rats and their metabolic, neuroendocrine and immune accompaniments. Medical Hydrology and Rehabilitation. 2012; 10(4): 91-113.

14. Kozyavkina NV, Gozhenko AI, Barylyak LG, Korolyshyn TA, Popovych IL. Polyvariance of immediate thyrotropic effects of Naftussya bioactive water, their neuroendocrine-immune support and predictability. Medical Hydrology and Rehabilitation. 2013; 11(4): 27-54.

15. Kozyavkina OV. Vegetotropic effects of bioactive water Naftussya in children with neuroendocrine-immune complex dysfunction, their endocrine-immune support and the ability to predict. Medical Hydrology and Rehabilitation. 2011; 9(2): 24-39.

16. Kozyavkina OV. Vegetotropic effects of Naftussya bioactive water in male rats and their endocrine, electrolyte and immune accompaniments. Medical Hydrology and Rehabilitation. 2012; 10(3): 65-92. 
17. Kozyavkina OV, Vis'tak HI, Popovych IL. Factor, canonical and discriminant analysis of vegetotropic effects and accompanying changes for thyroide, metabolic and haemodynamic parameters at the women, caused by bioactive water Naftussya. Medical Hydrology and Rehabilitation. 2013; 11(3): 4-28.

18. Kozyavkina OV, Kozyavkina NV, Gozhenko OA, Gozhenko AI, Barylyak LG, Popovych IL. Bioactive Water Naftussya and Neuroendocrine-Immune Complex [in Ukrainian]. Kyiv. UNESCO-SOCIO; 2015: 349 p.

19. Lapovets' LY, Lutsyk BD. Laboratory Immunology [in Ukrainian]. Kyiv; 2004: 173 p.

20. Marfiyan OM, Korolyshyn TA, Barylyak LG, Kovbasnyuk MM, Yavors'kyi OV, Zukow W, Popovych IL. Neuroendocrine-immune and metabolic accompaniments of cholecystokinetic effects of balneotherapy on spa Truskavets'. Journal of Education, Health and Sport. 2015; 5(5): 21-30.

21. Perederiy VG, Zemskov AM, Bychkova NG, Zemskov VM. Immune status, principles of its evaluation and correction of immune disorders [in Russian]. Kyiv. Zdorovya; 1995: $211 \mathrm{p}$.

22. Popadynets' OO, Gozhenko AI, Zukow W, Popovych IL. Relationships between the entropies of EEG, HRV, immunocytogram and leukocytogram. Journal of Education, Health and Sport. 2019; 9(5): 651-666.

23. Popovych AI. Features of the immunotropic effects of partial components of the balneotherapeutic complex of spa Truskavets'. Journal of Education, Health and Sport. 2018; 8(12): 919-935.

24. Popovych AI. Features of the neurotropic effects of partial components of the balneotherapeutic complex of spa Truskavets'. Journal of Education, Health and Sport. 2019; 9(1): 396-409.

25. Popovych IL. Stresslimiting Adaptogene Mechanism of Biological and Curative Activity of Water Naftussya [in Ukrainian]. Kyiv. Computerpress; 2011: 300 p.

26. Popovych IL, Barylyak LG. Influence of course using of bioactive water Naftussya on stress level at women with endocrine and gynecological pathology [in Ukrainian]. Medical Hydrology and Rehabilitation. 2009; 7(3): 100-118.

27. Popovych IL, Flyunt IS, Alyeksyeyev OI, Barylyak LG, Bilas VR. Sanogenetic Bases of Rehabilitation on Spa Truskavets' Urological Patients from Chornobylian Contingent [in Ukrainian]. Kyiv. Computerpress; 2003: 192 p.

28. Popovych IL, Gumega MD, Verba IE, Popovych AI, Korolyshyn TA, Tkachuk SP, Ostapenko VM, Zukow W. Comparative investigation effects on nervous and immune systems of bioactive water Naftussya spa Truskavets' and stable water solution of Boryslav's ozokerite. Journal of Education, Health and Sport. 2016; 6(4): 364-374.

29. Popovych IL, Kozyavkina NV. Metabolic support of thyrotropic effects of bioactive water Naftussya in women with thyroid hyperplasia [in Ukrainian]. Medical Hydrology and Rehabilitation. 2012; 10(4): 114-138.

30. Popovych IL, Ruzhylo SV, Ivassivka SV, Aksentiychuk BI (editors). Balneocardioangiology [in Ukrainian]. Kyiv. Computerpress; 2005: 229 p.

31. Popovych IL, Vis'tak (Markevych) HI, Humega MD, Ruzhylo SV. Vegetotropic Effects of Bioactive Water Naftussya and their Neuroendocrine-Immune, Metabolic and Hemodynamic Accompaniments [in Ukrainian]. Kyiv. UNESCO-SOCIO; 2014: 162 p.

32. Ruzhylo SV, Tserkovnyuk AV, Ророрvych IL. Актотропні ефекти бальнеотерапевтичного комплексу курорту Трускавець. Actotropic Effects of Balneotherapeutic Complex of Truskavets spa [in Ukrainian]. Kyiv. Computerpress; 2003: 131 p.

33. Vis'tak HI, Kozyavkina OV, Popovych IL, Zukow W. Vegetotropic effects of bioactive water Naftussya spa Truskavets' and their thyroide, metabolic and haemodynamic accompaniments at the women. Journal of Health Sciences. 2013; 3(10): 557-582.

34. Zukow W, Flyunt I-S S, Ponomarenko RB, Rybak NY, Fil' VM, Kovalchuk HY, Sarancha SM, Nahurna YV. Polyvariant change of step-test under the influence of natural adaptogens and their accompaniments. Pedagogy and Psychology of Sport. 2020; 6(2): 74-84. 